\title{
Crossed Immunoelectrophoresis and Crossed-line Immunoelectrophoresis of Salmonella dublin Antigens
}

\author{
By G. T. H. BROWN* AND P. W. JONES \\ Agricultural Research Council, Institute for Research on Animal Diseases, \\ Compton, Nr Newbury, Berkshire RG16 0NN
}

(Received 11 June 1979)

Crossed immunoelectrophoresis and crossed-line immunoelectrophoresis were used to detect 62 antigens in extracts of sonicated Salmonella dublin against an homologous antiserum. Comparison with six extracts of closely related bacteria showed that all but two of these antigens cross-reacted with at least one other extract.

\section{INTRODUCTION}

The serology of the salmonellas has been extensively investigated but most work has concentrated on the agglutinating antibodies. Agglutination reactions are useful in characterizing and identifying serotypes of Salmonella but are less satisfactory for identifying animals infected with the organism. In cattle, Hall et al. (1978) concluded that the lack of correlation between antibody titres, faecal excretion and persistence of infection in carcasses confirmed that the serum agglutination test was of no value in detecting latent carrier animals.

Precipitins to Salmonella typhi were studied by Olitzki \& Godinger (1963) who demonstrated that cross-reactions occurred with other members of the Enterobacteriaceae. Barber et al. (1969) commented on the importance of studying alternatives to agglutinins and also found that precipitins were shared between Salmonella serotypes and other Enterobacteriaceae.

Olitzki \& Godinger (1963) and Barber et al. (1969) recorded precipitation in an agar diffusion technique. Recently, quantitative immunoelectrophoresis has been used to study precipitins to many micro-organisms but it has not been applied to Salmonella. Such techniques are more sensitive than immunodiffusion and this paper describes an analysis of the antigens of $S$. dublin by means of crossed immunoelectrophoresis and crossed-line immunoelectrophoresis.

It was hoped that if additional antigens of $S$. dublin could be characterized and, particularly, if genus-specific antigens could be demonstrated it might be possible to detect animals infected with Salmonella by means of a precipitin test. It would also have made possible the analysis of antibodies produced following infection or immunization and distinguished those which were important in resistance to infection.

\section{METHODS}

Bacteria. Sixteen strains of bacteria were used in this investigation. Salmonella dublin strain 3246 was originally isolated by M. H. Hinton from a case of abortion in a dairy cow (Hall \& Jones, 1976). Salmonella pullorum was obtained from the Central Veterinary Laboratory (Weybridge) and Pseudomonas aeruginosa was strain NCTC 6749. Enterobacter aerogenes, Serratia marcescens, Salmonella agona, Salmonella senftenberg, Escherichia coli (serotypes E68II, E4, G1253, E57 and G205), Citrobacter freundii, Proteus mirabilis, Proteus vulgaris and Klebsiella pneumoniae were all isolated in this laboratory. 
Bacterial extracts. The bacterial extracts were prepared by a method similar to that of Høiby (1975). The organisms were cultivated either on buffered glucose nutrient agar (Jones \& Rutter, 1972) or, in the case of $S$. dublin extract (iii) (see below), in $100 \mathrm{ml}$ volumes of Bacto-tryptose broth (Jones, 1975) and incubated at $37^{\circ} \mathrm{C}$ for $18 \mathrm{~h}$. Bacteria ( $4 \mathrm{~g}$ wet wt) were made up to a final volume of $15 \mathrm{ml}$ with distilled water. The $E$. coli pool comprised equal quantities of the five serotypes. Equal quantities of Enterobacter aerogenes, Serratia marcescens, $C$. freundii, $K$. pneumoniae, $P$. mirabilis and $P$. vulgaris made up the Enterobacteriaceae pool.

Suspensions were sonicated three times for $45 \mathrm{~s}$ at $20 \mathrm{kHz}$ in the sealed-atmosphere treatment chamber of a Branson B12 sonifier. Sonicates were centrifuged at $30000 \mathrm{~g}$ for $1 \mathrm{~h}$ at $4{ }^{\circ} \mathrm{C}$, the supernatants were retained and the pellets were resuspended in distilled water to a final volume of $15 \mathrm{ml}$. This procedure was repeated and the pellets were discarded. The two supernatants were mixed in equal volumes and passed through a $0.22 \mu \mathrm{m}$ filter (Millipore). Three separate preparations of $S$. dublin extract were designated (i), (ii) and (iii).

Bacterial extracts were stored at $-20^{\circ} \mathrm{C}$ in $1 \mathrm{ml}$ portions. Protein concentrations (Table 1) were determined by the method of Lowry, using crystalline bovine serum albumin as a standard. Dry weights were calculated after heating $1 \mathrm{ml}$ of each extract at $160^{\circ} \mathrm{C}$ for $18 \mathrm{~h}$.

Antiserum. The antiserum was raised in rabbits by injecting $1 \mathrm{ml}$ of a $1: 1$ mixture of $S$. dublin extract and Freund's complete adjuvant intramuscularly into both hind legs of a rabbit. Booster doses of $0.5 \mathrm{ml}$ into each hind leg were given after a 6 week interval and the rabbits were bled out approximately 2 weeks later.

Immunoelectrophoresis. All bacterial extracts were examined by crossed immunoelectrophoresis (CIE) and crossed-line immunoelectrophoresis (CLIE). The CIE technique used was adapted from Weeke (1973). The buffer used in the electrophoresis tank contained $13.14 \mathrm{~g}$ barbitone sodium, $2.07 \mathrm{~g}$ barbitone and $0.4 \mathrm{~g}$ calcium lactate (Laurell, 1965) with the addition of $0.1 \mathrm{~g}$ sodium azide (Clarke \& Freeman, 1966) made up to 11 with distilled water ( $\mathrm{pH} 8 \cdot 6,0.078 \mathrm{M}$-barbitone). The buffer was diluted to $0.02 \mathrm{M}$ when used as a diluent for the $1 \%$ agarose. A gel thickness of $1.25 \mathrm{~mm}$ was used on $8 \times 8 \mathrm{~cm}$ glass plates and the runs in both dimensions were performed on a single plate.

Samples $(10 \mu \mathrm{l})$ of the bacterial extracts, either undiluted or diluted 1 in 5 in distilled water, were run in the first dimension. Second dimension gels contained 15 or $45 \mu \mathrm{l} S$. dublin antiserum per ml agarose in the case of undiluted bacterial extracts and 45,75 or $150 \mu \mathrm{l} \mathrm{S}$. dublin antiserum per ml agarose in the case of bacterial extracts diluted 1 in 5 . The gels were run on a water-cooled plate at $10 \mathrm{~V} \mathrm{~cm}^{-1}$ for approx. $1 \mathrm{~h}$ in the first dimension and at 2 to $3 \mathrm{~V} \mathrm{~cm}^{-1}$ for $17 \mathrm{~h}$ in the second dimension. The first dimension electrophoresis was halted when the bromophenol blue marker had travelled $6.5 \mathrm{~cm}$.

The CLIE method was described by Krøll (1973). The combination of $S$. dublin extract and antiserum comprised a reference system. A sample $(10 \mu \mathrm{l})$ of $S$. dublin extract was separated in the first dimension as in CIE. The second dimension was composed of an intermediate $2 \mathrm{~cm}$ wide gel containing either 150 or $25 \mu \mathrm{l}$ of the bacterial extract being examined per $\mathrm{ml}$ agarose and a $4.5 \mathrm{~cm}$ wide gel containing $300 \mu 1$ $S$. dublin antiserum. The equipment and voltages were as used for CIE.

Staining. Plates were washed five times in saline $(0.85 \%, \mathrm{w} / \mathrm{v})$ to remove unprecipitated protein and once in distilled water to remove salts. Plates were dried, stained for $20 \mathrm{~min}$ in $0.05 \%$ Coomassie brilliant blue in $7 \%(\mathrm{w} / \mathrm{v})$ acetic acid and decolorized by repeated washings in $7 \%(\mathrm{w} / \mathrm{v})$ acetic acid.

\section{RESULTS}

Salmonella dublin (iii) and $P$. aeruginosa extracts had protein concentrations of $7 \cdot 4$ and $6.4 \mathrm{mg} \mathrm{ml}^{-1}$ and dry weights of 11.9 and $15.5 \mathrm{mg} \mathrm{ml}^{-1}$, respectively. The other extracts contained $14 \pm 2.9 \mathrm{mg}$ protein $\mathrm{ml}^{-1}$ and had dry weights of $28.5 \pm 3.8 \mathrm{mg} \mathrm{ml}^{-1}$.

The CIE pattern produced by an $S$. dublin extract against the $S$. dublin antiserum is shown in Figs. 1 and 2. Fifty-three anodic precipitin lines (Fig. 1) and nine cathodic lines (Fig. 2) were obtained. Precipitin lines were not detected against pre-inoculation rabbit serum and none of the precipitin lines could be attributed to the cultivation medium.

The total number of precipitin lines produced when the 10 bacterial extracts were reacted against $S$. dublin antiserum, using CIE, ranged between 0 and 62 (Table 1). Salmonella dublin extracts (i) and (ii) produced identical patterns, while in comparison $S$. dublin extract (iii) lacked six anodic lines. Extracts of the three other Salmonella serotypes contained between 6 and 12 antigens less than $S$. dublin (i) and (ii). The extract prepared from the other members of the Enterobacteriacede (Enterobacteriaceae pool) lacked 8 antigens and 

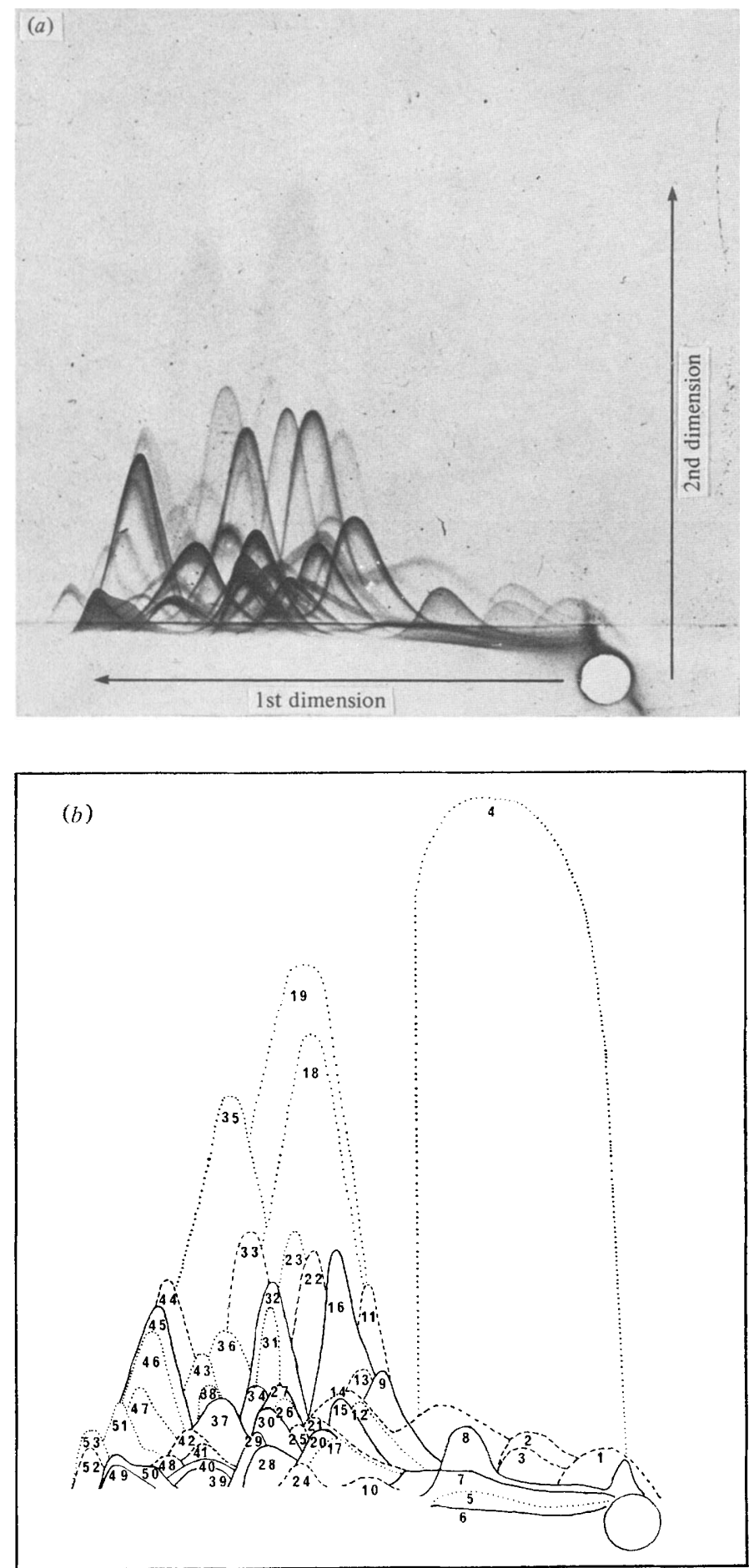

Fig. 1. Crossed immunoelectrophoresis of anodic precipitin lines formed by $S$. dublin extract (i) against $S$. dublin antiserum. (a) Anode to the left in the first dimension and at the top in the second dimension. (b) Drawing of $(a)$ and enumeration of 53 precipitin lines. 




1st dimension

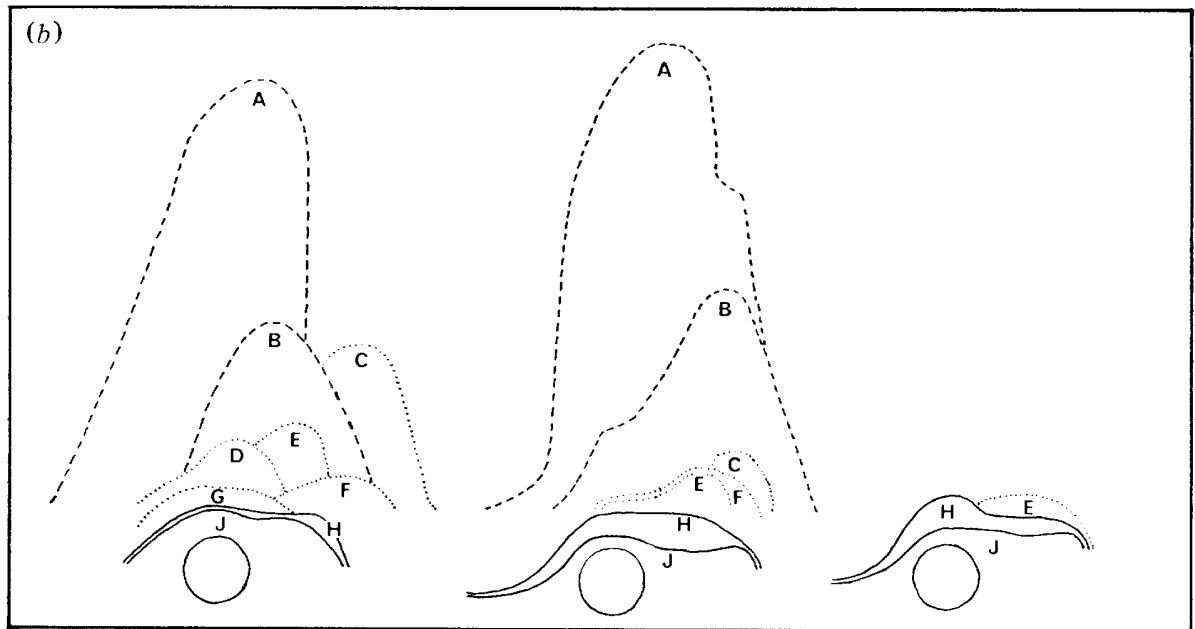

Fig. 2. Crossed immunoelectrophoresis of cathodic precipitin lines formed by $S$. dublin extract (i) against $S$. dublin antiserum. (a) Wells (from left to right) contained $S$. dublin sonicate unheated, heated at $60^{\circ} \mathrm{C}$ for $1 \mathrm{~h}$ and heated at $100^{\circ} \mathrm{C}$ for $30 \mathrm{~min}$. Anode to the left in the first dimension and at the bottom in the second dimension. $(b)$ Drawing of $(a)$ and enumeration of the precipitin lines.

Table 1. Protein concentrations of bacterial extracts and precipitin lines formed by these extracts against $S$. dublin antiserum

$\begin{array}{lcccc}\text { Bacterial extract } & \begin{array}{c}\text { Protein } \\ \text { concn } \\ \left(\mathrm{mg} \mathrm{ml}^{-1}\right)\end{array} & \begin{array}{c}\text { No. of } \\ \text { anodic } \\ \text { precipitin } \\ \text { lines }\end{array} & \begin{array}{c}\text { No. of } \\ \text { cathodic } \\ \text { precipitin } \\ \text { lines }\end{array} & \begin{array}{c}\text { Total no. } \\ \text { of } \\ \text { precipitin } \\ \text { lines }\end{array} \\ \text { dublin } \text { (i) } & 13 \cdot 9 & 53 & 9 & 62 \\ \text { dublin (ii) } & 11 \cdot 1 & 53 & 9 & 62 \\ \text { dublin (iii) } & 7 \cdot 4 & 47 & 9 & 56 \\ \text { pullorum } & 16 \cdot 0 & 44 & 6 & 50 \\ \text { agona } & 16 \cdot 8 & 51 & 5 & 56 \\ \text {. conftenberg } & 15 \cdot 6 & 50 & 5 & 55 \\ \text { Enterobacteriaceae } \text { pool } & 14 \cdot 6 & 42 & 3 & 45 \\ \text { aeruginosa } & 15 \cdot 3 & 48 & 6 & 54 \\ & 6 \cdot 4 & 0 & 0 & 0\end{array}$


Table 2. Comparison by crossed-line immunoelectrophoresis of the bacterial extracts with the reference system

\begin{tabular}{|c|c|c|}
\hline \multirow[b]{2}{*}{ Bacterial extract } & \multicolumn{2}{|l|}{ Antigens not detected } \\
\hline & Anodic precipitin lines* & $\begin{array}{c}\text { Cathodic } \\
\text { precipitin linest }\end{array}$ \\
\hline S. dublin (ii) & - & - \\
\hline S. dublin (iii) & $1,12,13,24,37,46$ & - \\
\hline S. pullorum & $5,6,7,20,21,23,27,44,45$ & $\mathrm{C}, \mathrm{D}, \mathrm{G}$ \\
\hline S. agona & 6,27 & $A, \vec{F}, \mathrm{G}, \mathrm{H}$ \\
\hline S. senftenberg & $6,27,40$ & $\mathrm{D}, \mathrm{E}, \mathrm{G}, \mathrm{J}$ \\
\hline E. coli pool & $5,6,7,18,20,21,27,28,38,40,45$ & B, D, E, G, H, J \\
\hline Enterobacteriaceae pool & $5,6,7,27,40$ & $\mathrm{G}, \mathrm{H}, \mathrm{J}$ \\
\hline$P$. aeruginosa & None cross-reacted & \\
\hline
\end{tabular}

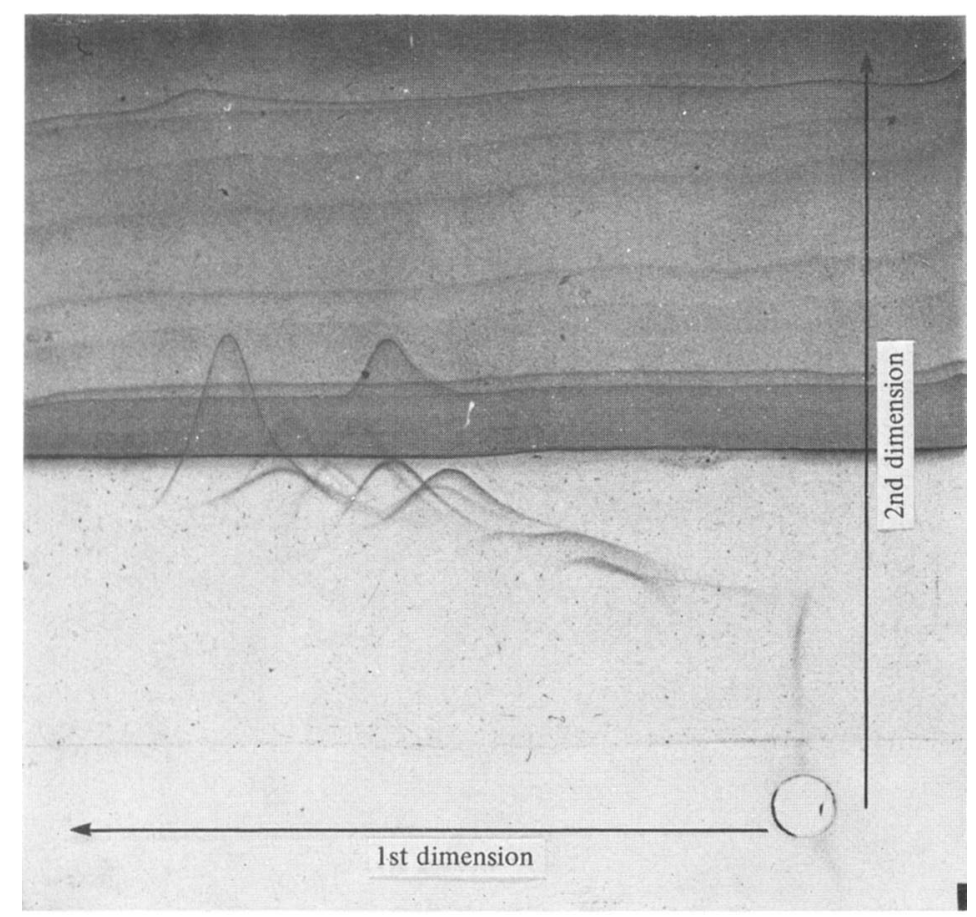

Fig. 3. Crossed-line immunoelectrophoresis of $S$. dublin extract (i) run against $S$. dublin antiserum with the $E$. coli pool extract in the intermediate gel. Anode to the left in the first dimension and at the top in the second dimension.

the extract prepared from five $E$. coli strains ( $E$. coli pool) lacked 17 antigens. The identity of the missing antigens was confirmed by CLIE (Table 2). The CLIE pattern formed against the $E$. coli pool is shown in Fig. 3.

Heating extracts at $60^{\circ} \mathrm{C}$ for $1 \mathrm{~h}$ demonstrated the presence of a maximum of 31 stable antigens (Table 3 ). The stability of particular antigens varied between extracts. However, there was no variability in the stability of antigens in the $S$. dublin extracts. Heating at $100{ }^{\circ} \mathrm{C}$ for 30 min demonstrated the presence of a maximum of six stable antigens (Table 4). 

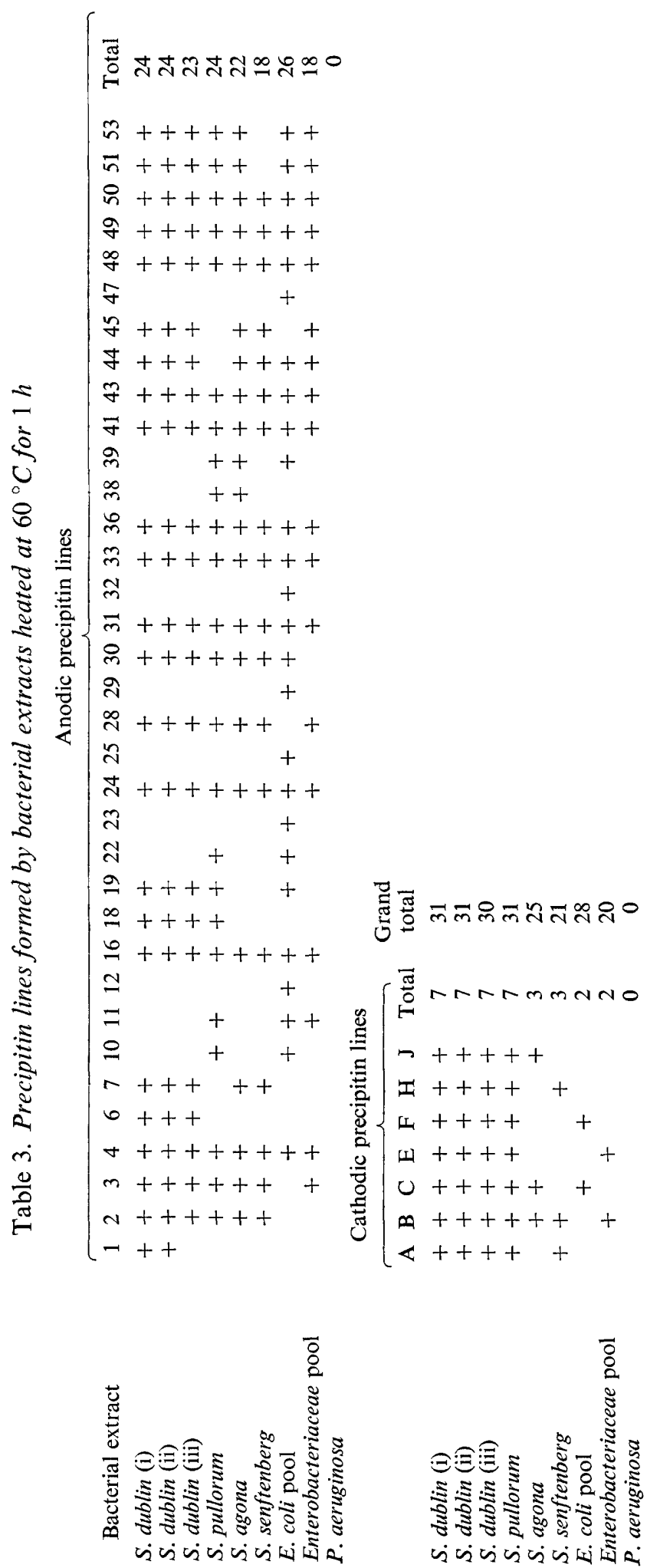
Table 4. Precipitin lines formed by bacterial extracts heated at $100^{\circ} \mathrm{C}$ for $30 \mathrm{~min}$

\begin{tabular}{|c|c|c|c|c|c|c|c|c|c|c|c|}
\hline \multirow[b]{2}{*}{ Bacterial extract } & \multicolumn{4}{|c|}{ Anodic precipitin lines } & \multicolumn{6}{|c|}{ Cathodic precipitin lines } & \multirow{2}{*}{$\begin{array}{c}\text { Grand } \\
\text { total }\end{array}$} \\
\hline & 4 & 6 & 31 & Total & $\mathrm{C}$ & $\mathrm{E}$ & $\mathrm{F}$ & $\mathrm{H}$ & $\mathbf{J}$ & Total & \\
\hline S. dublin (i) & + & + & + & 3 & & + & & + & + & 3 & 6 \\
\hline S. dublin (ii) & + & + & + & 3 & & + & & + & + & 3 & 6 \\
\hline S. dublin (iii) & + & + & + & 3 & & + & & + & + & 3 & 6 \\
\hline S. pullorum & + & & + & 2 & & + & & + & + & 3 & 5 \\
\hline S. agona & + & & + & 2 & & & & & + & 1 & 3 \\
\hline S. senftenberg & + & & + & 2 & & & & $t$ & & 1 & 3 \\
\hline E. coli pool & + & & + & 2 & + & & + & & & 2 & 4 \\
\hline Enterobacteriaceae pool & + & & + & 2 & & & & & & 0 & 2 \\
\hline$P$. aeruginosa & & & & 0 & & & & & & 0 & 0 \\
\hline
\end{tabular}

\section{DISCUSSION}

The bacterial extracts used were roughly comparable in protein content and dry weight, with the exception of $S$. dublin (iii) and $P$. deruginosa which contained less protein than the other strains but were similar in concentration to each other.

CIE of $S$. dublin extracts detected 62 precipitin lines; approximately eight times as many as were demonstrated in $S$. typhi by Olitzki \& Godinger (1963) who used diffusion techniques. Barber \& Eylan (1976) found that different batches of bacterial extract, although cultivated and prepared in the same way, varied in their antigenic content. The results obtained by CIE and CLIE of the $S$. dublin extracts (i) and (ii) (both grown on buffered glucose nutrient agar) were identical but $S$. dublin (iii) which was grown in Bacto-tryptose broth differed from the other two extracts of $S$. dublin. Six peaks were missing and the height of several peaks had changed. It would seem that the antigenic content of an extract may be changed by the growth medium.

Extracts of the salmonellas, E. coli pool and Enterobacteriaceae pool all presented similar CIE patterns (Table 1). However, certain antigens did not occur in every extract and the height of a number of the peaks was variable. This may be due to differences in the dry weight of the extracts or to actual differences in the concentrations of the antigens. Precipitin lines were not produced against $P$. aeruginosa. Høiby (1975) detected four antigens of $P$. aeruginosa which cross-reacted with several members of the Enterobacteriaceae and suggested that cross-reactions may not be apparent if the common antigens are of low concentration in the strain being investigated.

The CIE results were confirmed by those obtained with CLIE. The missing antigens in each bacterial extract could be distinguished (Table 2). The precipitin lines which formed between the antigens in the reference system and the antigens in the intermediate gel were continuous and there were no visible spurs. This indicates a reaction of 'identity' (Axelson et al., 1973) rather than partial identity (Bock \& Axelson, 1973). Examination of the CLIE data (Table 2) reveals that only antigens 6 and 27 are specific to $S$. dublin.

Barber \& Eylan (1976) suggested that the antigenicity of bacterial extracts might alter after they had been heated. Table 3 shows precipitin lines formed by the bacterial extracts after they had been heated at $60^{\circ} \mathrm{C}$ for $1 \mathrm{~h}$. The heat stability of individual antigens in the $S$. dublin extracts was identical but the corresponding antigens in the other extracts did not necessarily have the same heat stability as those of $S$. dublin or each other. It therefore seems that although an antigen may be common to several bacteria its structure may be sufficiently different as to affect its heat stability without affecting its antigenicity. There is not such a marked variation in stability of antigens heated at $100{ }^{\circ} \mathrm{C}$ for $30 \mathrm{~min}$.

The high degree of cross-reaction reduces the potential of these techniques as detectors of humoral responses or as taxonomic tools. It is, however, in accordance with the suggestions of Høiby (1975) and Wilson \& Miles (1975) who proposed that natural immunity may be explained in terms of earlier contact with organisms that share certain antigens. 
We would like to thank I. Jebbett and G. Fletcher for preparing the photographic plates.

\section{REFERENCES}

Axelsen, N. H., Bock, E. \& Krøll, J. (1973) Comparison of antigens: the reaction of 'identity'. Scandinavian Journal of Immunology 2, Suppl. 1, 91-94.

BARBER, C. \& EylaN, E. (1976). Cross-protection induced in mice by immunizations with proteins of related bacteria species. Zentralblatt für Bakteriologie, Parasitenkunde, Infektionskrankheiten und Hygiene (Abteilung I, Originale A) 234, $46-52$.

Barber, C., Eylan, E. \& Keydar, Y. (1969). Immunological specificities of polysaccharides and proteins from Salmonellae of group C. Pathologia et microbiologia 33, 23-34.

Bock, E. \& AXELSEN, N. H. (1973). Comparison of antigens: the reaction of partial identity. Scandinavian Journal of Immunology 2, Suppl. 1, 9599.

Clarke, H. G. M. \& Freeman, T. (1966). A quantitative immunoelectrophoresis method (Laurell electrophoresis). Protides of the Biological Fluids 14, 503-509.

Hall, G. A. \& Jones, P. W. (1976). An experimental study of Salmonella dublin abortion in cattle. British Veterinary Journal 132, 60-65.

Hall, G. A., Jones, P. W., Aitken, M. M. \& PArsons, K. R. (1978). The serology of experimental Salmonella dublin infections of cattle. Journal of Hygiene 81, 31-41.

HøiвY, N. (1975). Cross-reactions between Pseudo- monas aeruginosa and thirty-six other bacterial species. Scandinavian Journal of Immunology 4, Suppl. 2, 187-196.

Jones, G. W. \& Rutter, J. M. (1972). Role of the K88 antigen in the pathogenesis of neonatal diarrhea caused by Escherichia coli in piglets. Infection and Immunity 6, 918-927.

JONES, P. W. (1975). The effect of storage in slurry on the virulence of Salmonella dublin. Journal of Hygiene 74, 65-70.

KRøLL, J. (1973). Crossed-line immunoelectrophoresis. Scandinavian Journal of Immunology 2, Suppl. 1, 79-81.

LAURELl, C.-B. (1965). Antigen-antibody crossed electrophoresis. Analytical Biochemistry 10, 358 361.

Olitzki, A. L. \& Godinger, D. (1963). Interfamiliar antigenic relationships between Enterobacteriaceae, Brucellaceae and Pseudomonadacaea revealed by the agar gel precipitation technique. Bolletino dell'Istituto sieroterapico milanese $\mathbf{4 2}$, 213-232.

WEEKE, B. (1973). Crossed immunoelectrophoresis. Scandinavian Journal of Immunology 2, Suppl. 1, 47-56.

Wilson, G. S. \& Miles, A. A. (1975). Topley and Wilson's Principles of Bacteriology, Virology and Immunity, 6th edn, pp. 1436-1440. London: Edward Arnold. 